\title{
A pharmacokinetic and pharmacodynamic study with a single implant containing 3-ketodesogestrel (Implanon $\left.{ }^{\circledR}\right)$
}

\author{
Biran Affandi' ${ }^{1}$, Suharti K. Suherman ${ }^{2}$, Tjeerd Korver ${ }^{3}$, T.B. Paul Geurts ${ }^{3}$, H.J.T. Coelingh Bennink ${ }^{3}$,
} W. Gadroen ${ }^{4}$

\begin{abstract}
Abstrak
Untuk mengetahui farmakokinetik dan farmakodinamik Implanon ${ }^{\circledR}$, dilakukan pemasangan Implanon ${ }^{\circledR}$ pada 15 wanita pasangan usia subur, umur 20 - 35 tahun, haid teratur dan tidak sedang menyusukan. Darah vena diambil sebelum dan sesudah implan dipasang sesuai jadwal. Kadar serum etonogestrel (3-ketodesogestrel) 6 minggu setelah pemasangan: $709 \mathrm{pg} / \mathrm{ml}$ dan turun menjadi $388 \mathrm{pg} / \mathrm{ml}$ pada bulan keenam. Selanjutnya secara perlahan turun, menjadi $169 \mathrm{pg} / \mathrm{ml}$ pada tahun kelima. Kadar P4 selalu di bawah $16 \mathrm{nmolh}$. Penurunan kadar $E_{2}$ terjadi pada 12 bulan pertama. Setelah itu kadar $E_{2}$ kembali mendekati kadar sebelum pemasangan. Bahkan kadang-kadang lebih tinggi. Terdapat variasi intra dan antar subyek. Pada $11 / 2$ tahun pertama kadar SHBG di bawah kadar sebelum pemasangan. Selanjutnya meningkat mendekati kadar sebelum pemasangan. Tidak ditemukan kehamilan. Setelah pencabutan, dilaporkan terjadi kehamilan pada 2 subyek. Kembalinya kesuburan berdasarkan kembalinya haid dan kembalinya kadar progesteron fase luteal, terjadi pada 7 dari 8 subyek, 3 bulan setelah Implanon ${ }^{\circledR}$ dicabut.
\end{abstract}

\begin{abstract}
With the objective to investigate the pharmacokinetic and pharmacodynamic profile of a single implant containing 3-ketodesogestrel (Implanon $\left.{ }^{\circledR}\right), 15$ healthy women of fertile aged between 20 and 35, with regular cycles, and not breastfeeding were recruitted. Blood sample were drawn before and after implant inserted according to schedule. Serum concentration of 3 keto-desogestrel for the first six weeks after implant insertion was $709 \mathrm{pg} / \mathrm{ml}$ and had decreased to $388 \mathrm{pg} / \mathrm{ml}$ at six months. Thereafter concentration further decreased slowly with time (fifth year mean $169 \mathrm{pg} / \mathrm{ml}$, range 141 - $204 \mathrm{pg} / \mathrm{ml}, \mathrm{n}=7$ ). Maximum $P$ concentrations remained below $16 \mathrm{nmol} / \mathrm{l}$ in the whole treatment period for the majority of subjects. In four subjects maximum $P$ concentrations exceeding 16 nmoll the first six weeks. Reduced $E_{2}$ concentrations were observed during the first 12 months. Thereafter mean concentrations were close to, and sometimes exceeding, those observed before insertion. A large inter-subject and intra-subject variation was observed. During the first $11 / 2$ year mean and median $S H B G$ concentrations were below screening values. Thereafter, SHBG concentrations were close to the screening values. No pregnancies occured during treatment. No subjects discontinued due to bleeding irregularities or amenorrhoea. Overall reference periods $(R P s)$, the prevalence of a amenorrhoea ranged women 0 (for 9 out of 20 reference periods) and 33.3\%. No amenorrhoea occurred from $R P 14$ onwards. For infrequent bleeding the range was between $20.0 \%$ and $73.3 \%$, for number of bleeding-spotting days $R P$ ranged from 16.5 to 31.7. The mean number of bleeding-spotting episodes ranged from 1.9 to 3.7. Two post-treatment pregnancies were reported. Return of fertilty, judged from return of menses or return of luteal phase progesterone levels, could be confirmed to occur within 3 months after removal of the implant in seven out of eight available subjects.
\end{abstract}

Keywords: Implanon ${ }^{\circledR}$, implant contraceptive, phamacokinetic, pharmacodynamic.

Folkman and Long in 1964 published their findings that silastic tubes could serve as a reservoir for the prolonged administration of a drug. Two years later, Dziuk and Cook found that the in vitro release of

\footnotetext{
${ }^{1}$ Klinik Raden Saleh, Department of Obstetrics and Gynecology Faculty of Medicine, University of Indonesial Dr. Cipto Mangunkusumo National Hospital, Jakarta, Indonesia.

${ }^{2}$ Department of Pharmacology, Faculty of Medicine, University of Indonesia, Jakarta, Indonesia

${ }^{3}$ Clinical Development Department and Medical Services

Department, NV Organon Oss, The Netherland

${ }^{4} N V$ Organon Indonesia
}

steroids from silastic capsules was practically constant and independent of the drug concentration inside the tube.1,2

Based on the above studies, implantable contraceptives have been developing. In 1983 Norplant ${ }^{\circledR}$ became the first and only available implantable contraceptive to be introduced in family planning program.3,4 By March 1997 there were more than 3 million women in the world used Norplant ${ }^{\circledR}$ as their contraceptive method. More than $75 \%$ of them were Indonesia women.

Contraceptive implants are a successful method for long-term prevention of pregnancy. With the devel- 
opment of synthetic polymers, it has become possible to develop hormonal delivery systems with long duration of action and continuous release of the drug. Advantages of the long-term contraceptive implants are lack of concern for compliance and prompt return of fertility after removal. Furthermore, the parenteral route of administration results in a lower metabolic burden on the liver than with oral contraceptives. 3,4 Studies indicated that implantable contraceptive with 3-ketodesogestrel is a promising method for further investigation. ${ }^{5-8}$

NV Organon (Oss, The Netherlands) has developed a single-rod implant (Implanon ${ }^{\circledR}$ ). The rod is made of an ethylene vinyl acetate copolymer (EVA) with a core containing approximately $68 \mathrm{mg}$ of Org 3-ketodesogestrel or desogestrel (ENG).

The initial release rate of the implant is approximately $67 \mu \mathrm{g} / \mathrm{day}$ which slowly decreases over time. The constant release profile results in sufficiently high plasma ENG concentrations ( $>90 \mathrm{pg} / \mathrm{ml}$ ) to inhibit ovulation for at least three years.

ENG is a progestin, structurally derived from 19nortestoterone; it is the biologically active metabolite of desogestrel (DSG). DSG is the progestin component of a number of widely used oral contraceptives with a well established efficacy and safety profile. The characteristics of the implant's EVA membrane, combined with the high specific progestin activity of ENG, allow the use of a single-rod system with a low and almost zero-order release. As a consequence of these proporties, dose-related side-effects are minimised. However, known typical disadvantage of progestin-only methods is disruption of the normal menstrual cycle, including amenorrhoea.

With the objective to investigate the pharmacodynamic and pharmacokinetic of a single-rod implant (Implanon ${ }^{\circledR}$ ), a phase II study was conducted at Klinik Raden Saleh, Department of Obstetrics and Gynecology, University of Indonesia/Dr. Cipto Mangunkusumo National Hospital, Jakarta, Indonesia between June 1989 through May 1995. The study was approved by the ethical committee.

\section{MATERIAL AND METHODS}

\section{Implant}

Implanon ${ }^{\circledR}$ is a single-rod implant with a length of 4 $\mathrm{cm}$ and a diameter of $2 \mathrm{~mm}$ containing approximately
$68 \mathrm{mg}$ of ENG. The rod is made of EVA with an ENG core surrounded by an EVA membrane. The initial release rate of ENG from Implanon ${ }^{\circledR}$ is approximately $67 \mu \mathrm{g} /$ day. Implanon ${ }^{\circledR}$ is delivered in the needle of a sterile, disposable, specially designed inserter.

Implanon ${ }^{\circledR}$ was individually packed in almunium sachet, manufactured by NV Organon, Oss, Holland.

\section{Design of the study}

A total of 15 healthy women were recruited. Inclusion criteria were healthy women of proven fertility (child and/or abortion), willing to give written informed concent, willing to rely on the one rod - implant method for contraception with additional use of condoms, willing to return to the clinic for regularly scheduled visits and be accessible for follow-up, having regular menstrual cycles between 24-35, age 2035 at acceptance, and nor currently pregnant or breast feeding.

Exclusion criteria were subjects are not eligible, within two weeks after an abortion, before the first menses after delivery, before the first spontaneous menstrual bleeding after discontinuation of oral contraceptives, and within six months after the last injection of contraceptive steroids. Subjects should not have a history of, pelvic inflammatory disease (PID)/ Salpingitis since last pregnancy, ectopic pregnancy, any malignant disease, persistent abnormal genital bleeding. Abnormal menstrual cycle (persistent irregular inter menstrual bleeding or amenorrhoea), breast discharge, thrombophlebitis, thromboembolism, or severe cardiovascular problems, mental illness, depression or epilepsy, severe and/or frequent headaches, and diabetes mellitus.

There should be no current clinical evidence of, blood pressure greater than 140 systolic or 90 diastolic, jaundice, PID/Salpingitis, breast discharge, mental illness, manifest anaemia $(<10 \mathrm{~g}$ haemoglobin $[\mathrm{Hb}] / 100 \mathrm{ml}$ blood), severe hirsutism, pregnancy, positive urinary glucose, pap smear grade III or above, thrombophlebitis, and use of enzyme inducers or inhibitors.

\section{Screening assessment}

After a subject met all entry criteria and a writen informed consent form was signed, screening assessments were done. Results of these assessments has to be available before implantation. During this period of screening assessment, blood sampling had already 
started (see Table 1). After a subject was considered eligible, the Implanon ${ }^{\circledR}$ was inserted within five days of the onset of the menses.

Table 1. Screening assessments

\begin{tabular}{lllll}
\hline $\begin{array}{l}\text { Time in weeks } \\
\text { (relative to implantation) }\end{array}$ & $\begin{array}{c}-4 \\
\text { or earlier }\end{array}$ & -3 & -2 & -1 \\
\hline Checklist selection criteria & - & & \\
\hline $\begin{array}{l}\text { Gynecological history taking, } \\
\text { general, physical and pelvic } \\
\text { examination, Pap smear, Hb }\end{array}$ & & & \\
\hline
\end{tabular}

\begin{tabular}{lllll}
\hline Provide diary card & $\bullet$ & & & \\
\hline Blood sampling : & $\bullet$ & $\bullet$ & $\bullet$ & $\bullet$ \\
$\quad$ E2 & 2 & 2 & 2 & 2 \\
- & 2 & 2 & 2 & 2 \\
- ENG & 1 & - & 1 & - \\
- SHBG & 1 & - & 1 & - \\
\hline
\end{tabular}

$l$ one blood sample/analysis per week

2 two blood samples/analyses per week

- no analysis

\section{Procedure for insertion}

Insertion of the implant was performed between the first and the the fifth day of the subject's menstrual flow. Implanon ${ }^{\circledR}$ was inserted on the inside of the upper (non-dominant) arm, 6 to $8 \mathrm{~cm}$ above the elbow in the groove between the biceps and triceps (sulcus bicipitalis medialis). The area of insertion was thoroughly cleansed with a antiseptic prior to insertion. Using a local anaesthetic, $1 \%$ lidocaine, the insertion area was anaesthetised just below the skin along the insertion 'canal'. An anaesthetic spray could also be used to anaesthetise the skin.

The inserter was entered through the anaesthetised 'canal' to the full length of the needle. The seal of the inserter was broken by pressing the plunger support. The plunger was then turned 90 or 180 degrees. While the plunger was fixed against the arm, the inserter was slowly pulled out of the arm with the plunger tightly held against the arm. A pressure bandage with sterile gauze was applied to minimize bruising. The subject was told to keep the bandage clean and dry for four days.

\section{Procedure for removal}

The implant was located by palpation. The subject's arm was washed and antiseptic applied. A small amount of local anaesthetic (1\% lidocaine) was applied under the implant. After machine a $2 \mathrm{~mm}$ incision, the implant was gently pushed toward the incision until type tip was visible. The implant was then grasped with forceps and removed. If the implant could not be pushed into the incision, closed forceps were inserted into incision in order to gently dissect the tissues around the implant. While the tissues were being dissected, the implant was pushed toward the incision. After removal of the implant, the incense was closed and bandaged.

The implant was to remain in situ for $24,36,48$ or 60 months, depending on the willingness of the volunteer to continue the study. During the whole study period occurrence of adverse experiences as well as use of concomitant medication was reported. If pregnancy was suspected at any time in the study, a pregnancy test was performed. In addition, the subject collected data on her bleeding pattern in a diary card. At regular time intervals the subjects returned to the clinic to exchange the diary card.

Subjects returned twice weekly to the clinic for hormone determinations during certain time intervals: in the first year of treatment from weeks 1 to 6,24 to 29 and 48 to 53 , in the second as well as in the third year from weeks 20 to 25 and 46 to 51 , and in the fourth and fifth year from weeks 11 to 14,24 to 27,37 to 40 and 50 to 53 . In these periods circulating progsterone $(\mathrm{P})$ and estradiol $\left(\mathrm{E}_{2}\right)$ were determined twice weekly, whereas ENG and SHBG were measured once every two weeks. However, during the fourth and fifth treatment year ENG was measured once a week while SHBG measurement were not done (see Table 2).

Additionally, during the fifth year of treatment blood biochemistry was investigated alkalic phosphatase, alanine amino transferase (ALAT), aspartate amino atranferase (ASAT), urea, creatinine, triglycerides, total cholesterol, and high density lipoprotein (HDL) cholesterol and low density lipoprotein (HDL) cholesterol and low density lipoprotein (LDL) cholesterol, fasting blood sugar and post-prandial blood sugar.

Upon implant removal at any time a general medical and pelvic examination, as well as a cervical smear was made. ENG was measured just prior to removal and 24, 48 and 96 hours after removal. Post-treatment the return of menses was investigated. Blood samples were drawn for E2 and P analysis. For three months 
Table 2. Assessment during treatment

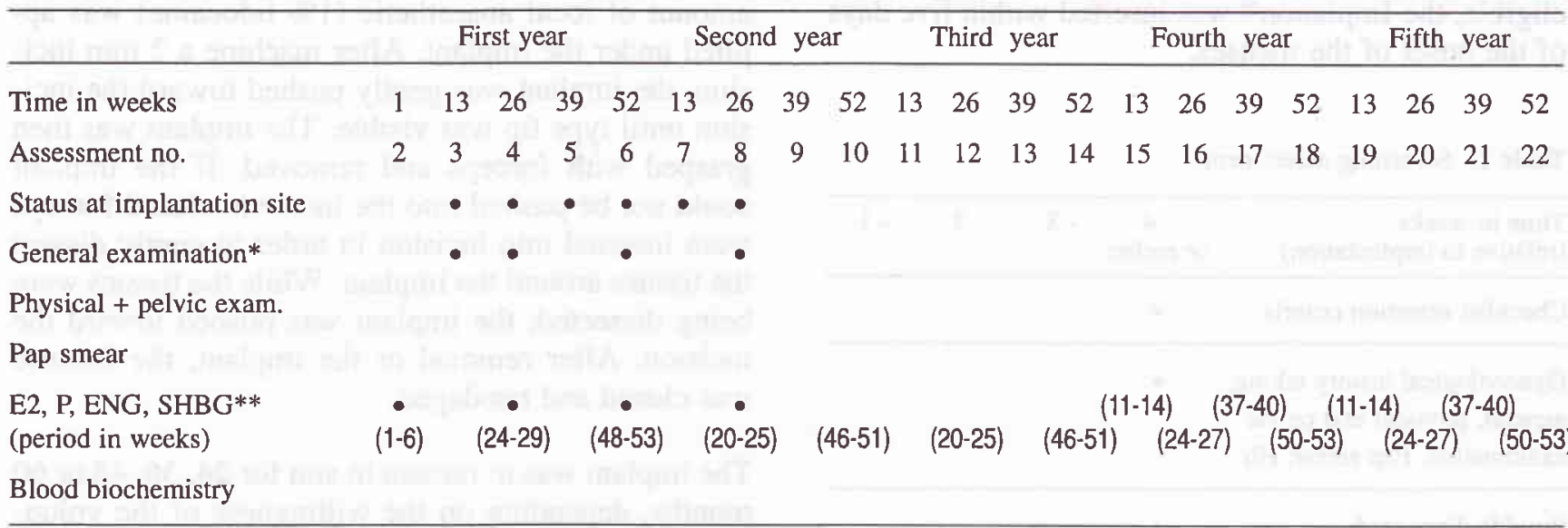

* Including blood pressure, body weight, $\mathrm{Hb}$

** Regularly assessed over a 6-week period (treatment year 1-3) or a-4 period (year 4-5), SHBG was not measured in the fourth and fifth year. Week numbers (each treatment year starts with week 1) are given in brackets.

Note: During assessment 2 the implant was to be inserted. Concomitant medication, AEs, pregnancy test if suspected, and bleeding data were to be collected/reported throughout

post-treatment the subject was requested to use a diary card. If a pregnancy occurred during this posttreatment period, it was to be followed for pregnancy outcome and paediatric evaluation. During the whole study period subjects were advised to use additional non-hormonal protection if ENG concentrations were below $120 \mathrm{pg} / \mathrm{ml}$. At extended treatment year 4, subjects were strongly recommended to take another form of non-hormonal contraceptive, preferably IUD.

The measurement of E2, P were performed in Jakarta following common protocols and reagents provided by the WHO Matched Reagent Programme. 9,10 While the measurement of ENG and SHBG were carried out in Jakarta and Oss according to previously described radioimmunoassay procedure. ${ }^{11-3}$

\section{RESULTS AND DISCUSSION}

\section{Profile of the subjects}

A total of 15 women were recruited into the study. The physical details of all subjects are shown in Table 3 .

Age ranged from 27 to 34 years with an overall mean value of $29.7 \pm 2.3$ years. Quetelet (body mass) index ranged from 16 to 26 with and overall mean of 19.7 $+2.9 \mathrm{~kg} / \mathrm{m}^{2}$. All subjects had been pregnant more than once before. All subjects had used some kind of contraception before; pelvic and physical examinations did not demonstrate any abnormalities. All cervical smear results at screening were either Pap class I or II. The mean duration of menstrual bleeding was $5.8 \pm 1.0$ days.

Table 3. Profile of the subjects $(\mathrm{N}=15)$

\begin{tabular}{lrrr}
\hline \multicolumn{1}{c}{ Characteristic } & Mean & \pm & SD \\
\hline Age (years) & 29.7 & \pm & 2.3 \\
Height $(\mathrm{cm})$ & 154.1 & \pm & 3.6 \\
Weight $(\mathrm{kg})$ & 46.7 & \pm & 6.3 \\
Quetelet Index $(\mathrm{kg} / \mathrm{m} 2)$ & 19.7 & \pm & 2.9 \\
Duration of meristrual bleeding (days) & 5.8 & \pm & 1.0 \\
\hline
\end{tabular}

\section{Pharmacodynamics}

\section{Progesteron $(P)$}

In Table 4 , frequencies of maximum $\mathrm{P}$ concentrations categorised as $\leq 10 \mathrm{nmol} / 1, \geq 10-\leq 30 \mathrm{nmol} / 1$ and $\geq 30$ $\mathrm{nmol} / \mathrm{l}$, are displayed for each monitoring period. The number of subjects with $P$ concentrations $>16 \mathrm{nmol} / \mathrm{l}$ is also given in Table 4. 
Table 4. Frequency table of maximum progesterone per assessment

\begin{tabular}{|c|c|c|c|c|c|c|}
\hline \multirow[t]{2}{*}{ Assessment } & \multirow[t]{2}{*}{$\mathrm{N}$} & \multicolumn{3}{|c|}{$\begin{array}{l}\text { Number of subjects } \\
\text { with concentrations }\end{array}$} & \multirow{2}{*}{\multicolumn{2}{|c|}{$\begin{array}{c}\text { Number of subjects } \\
\text { with concentrations } \\
\geq 16 \\
\text { nmol/l }\end{array}$}} \\
\hline & & $\begin{array}{c}<10 \\
\mathrm{nmol} / \mathrm{l}\end{array}$ & $\begin{array}{l}10-<30 \\
\mathrm{nmol} / \mathrm{l}\end{array}$ & $\begin{array}{c}\geq 30 \\
\text { nmol/l }\end{array}$ & & \\
\hline Screening & 15 & 2 & 1 & 12 & 13 & \\
\hline Week 1-6 & 15 & 11 & 2 & 2 & 2 & \\
\hline Week $24-29$ & 15 & 15 & & & & \\
\hline Week 48-53 & 15 & 15 & & & & \\
\hline Week 72-77 & 15 & 14 & & 1 & 1 & \\
\hline Week 98-104 & 15 & 15 & & & & \\
\hline Week 124-129 & 15 & 15 & & & & \\
\hline Week 150-155 & 15 & 15 & & & & \\
\hline Week $167-170$ & 10 & 10 & & & & \\
\hline Week 180-183 & 10 & 9 & 1 & & 1 & \\
\hline Week 193-196 & 10 & 10 & & & & \\
\hline Week 206-209 & 10 & 9 & 1 & & & \\
\hline Week 219-222 & 7 & 7 & & & & \\
\hline Week 232-235 & 7 & 6 & 1 & & 1 & \\
\hline Week $245-248$ & 7 & 7 & & & & \\
\hline Week 258-261 & 7 & 7 & & & & \\
\hline
\end{tabular}

Progesterone levels $\geq 16 \mathrm{nmol} / \mathrm{l}$ were occasionally observed:

- During the first six weeks after insertion, one Subject once displayed a value of $30.2 \mathrm{nmol} / \mathrm{l}$ (bounded by 0.6 and $8.0 \mathrm{nmol} / \mathrm{l}$ measured at start and end of the same week, respectively). She maintained progesterone levels $>30 \mathrm{nmol}$ from 4 days before insertion until day 11 after insertion. The same subjects also had progesterone values $>16 \mathrm{nmol} / \mathrm{l}$ (but $<30 \mathrm{nmol} / \mathrm{l}$ ) from Day 21 to day 42.

- During the 72-77 weeks assessment, a second subject displayee a progestrone value of $128.8 \mathrm{nmol} / \mathrm{l}$ at study Day 537; the values measured at the start and the end of the same week were 0.9 and 0.8 nmol/l, respectively.

- During the week 180-183 assessment, the first measurement of a third subject revealed a progesterone value of $16.8 \mathrm{nmol} / \mathrm{l}$, which was followed by $1.2 \mathrm{nmol} / 14$ days later. The same subject displayed during the week 232-235 assessment progesterone values of 22.9 (Day 1653) and 16.6 $\mathrm{nmol} / \mathrm{l}$ (Day 1656). These two values were preceded by $2.5 \mathrm{nmol} / \mathrm{l}$ (Day 1650) and followed by $1.8 \mathrm{nmol} / \mathrm{l}$ (Day 1660).
According to Landgren et al,14 progesterone levels $>16 \mathrm{nmol} / \mathrm{l}$, sustained for at least 5 days, are compatible with ovulation. This only applies the second and third subjects and, who had more than one measurement $>16 \mathrm{nmol} / \mathrm{l}$. For the second subject the pattern would be compatible with an ovulation having occurred by Day 8-11 before implantation; in the second sequence of evaluated progesterone levels the levels were lower and suggestive of a luteinized enraptured follicle also in view of the low E2 levels during the same period. All subsequent measurements showed suppressed progesterone. For the third subject progesterone values $>16 \mathrm{nmol} / \mathrm{l}$ were observed at the first measurement of the week 180-183 assessment and gain during the week 232-235 assessment. In both cases it cannot be established whether the elevated levels were maintained sufficiently long, because of the intervals between subsequent measurement. But, because all other measurements, i.e. up to and including the last treatment assessment of weeks 258-261, showed suppressed progesterone levels and because the observed values were much lower than the screening peak value of $62.0 \mathrm{nmol} / \mathrm{l}$, it is likely that some luteinisation rather than ovulation occurred in this subject.

\section{$17 \beta$ - Estradiol $\left(E_{2}\right)$}

In Table 5, the most important statistics in relation to $E_{2}$, concentrations are presented. Summary statistics of within-subject mean, minimum, median and maximum $\mathrm{E}_{2}$ concentrations are given per assessment period.

In Figure 1, the means (depicted by stars and joined by dashed lines), median (joined by lines), interquartile and P05-P95 ranges of within-subject mean $E_{2}$ concentration are graphically displayed.

A substantial decrease in the mean. SD and median of the within-subject mean $\mathrm{E}_{2}$ concentrations was observed during the first six weeks after insertion. At six and 12 months moderately reduced values were still observed, but thereafter values were close to and after two years exceeding the screening value. This suggests that the majority of subjects had reduced mean $\mathrm{E}_{2}$ concentrations during the initial one to two years, which thereafter increased to values close to or even exceeding screening values. Inspection of the individual mean $E_{2}$ concentrations confirmed this overall pattern and showed also a large intra-subject variation. 
Table 5. Summary table of $17 \beta$-Estradiol

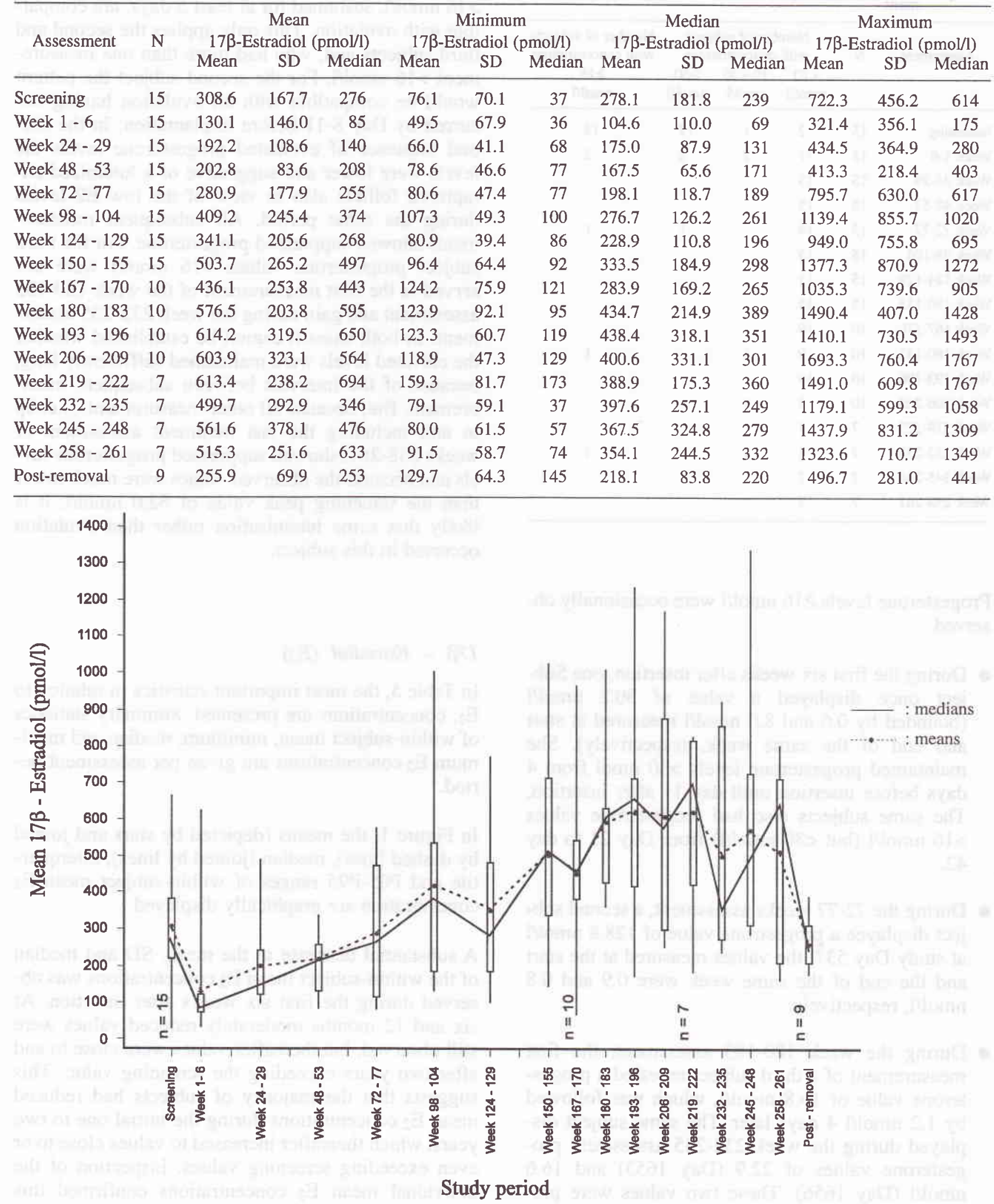

Figure 1. Mean, median, interquartile and P05-95 ranges of mean $E_{2}$ concentrations 
Table 6. Summary table of SHBG

\begin{tabular}{llllllll}
\hline & & \multicolumn{3}{c}{ Mean SHBG (nmol//) } & \multicolumn{3}{c}{ relative change from baseline SHBG* } \\
\cline { 3 - 8 } Assessment & $\mathrm{N}$ & Mean & SD & Median & Mean & SD & Median \\
\hline Screening & 15 & 77.5 & 36.6 & 61 & & & \\
Week 1-6 & 15 & 45.3 & 16.2 & 39 & -38.9 & 15.2 & -39 \\
Week 24-29 & 15 & 56.6 & 20.3 & 50 & -23.8 & 15.9 & -18 \\
Week 48-53 & 15 & 54.4 & 18.4 & 46 & -25.6 & 19.7 & -24 \\
Week 72-77 & 15 & 58.2 & 21.6 & 53 & -21.6 & 16.3 & -20 \\
Week 98-104 & 15 & 74.1 & 31.6 & 66 & -2.1 & 18.1 & -6 \\
Week 124-129 & 15 & 66.6 & 25.5 & 57 & -10.9 & 22.4 & -10 \\
Week 150-155 & 15 & 70.1 & 20.0 & 65 & -4.6 & 19.0 & -2 \\
\hline
\end{tabular}

* \% change of within subject mean SHBG from baseline (i.e. last screening value)

\section{Sex hormone binding globulin (SHBG)}

Summary statistics of within-subject mean, and relative change from baseline of SHBG concentrations per assessment period are presented in Table 6 . With respect to relative change from baseline, the latest screening value is used as baseline value. Judging from the mean and median relative changes from baseline, SHBG was suppressed during the initial $11 / 2$ years of treatment. Thereafter, SHBG concentrations were also to the screening values.

\section{Pharmacokinetics}

During the first three treatment years, per subject three ENG determinations (biweekly during 6 weeks)

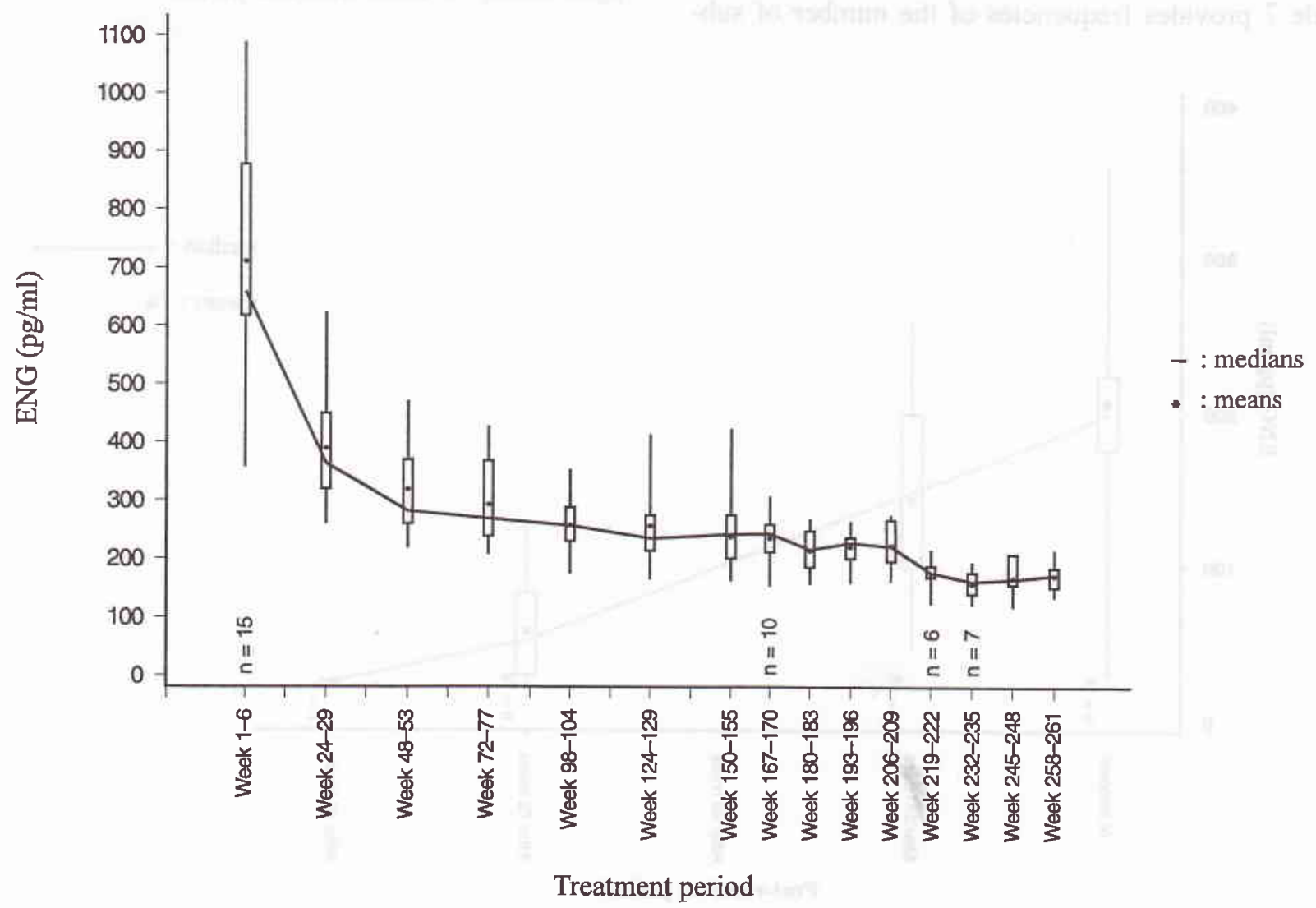

Figure 2. Mean, median, interquartile and P05-95 ranges of mean ENG concentration measured during treatment 
were performed in each monitoring period. During treatment years four and five, four determinations per period (weekly during 4 weeks) were performed in each subject.

In Figure 2 the mean (depicted by stars), median (joined by lines), interquartile and P05-P95 range of on-treatment within-subject mean ENG concentrations are displayed.

During the first six weeks after implant insertion the within-subject mean ENG concentration was on average $709.3 \mathrm{pg} / \mathrm{ml}$ (SD $194.5 \mathrm{pg} / \mathrm{ml}, \mathrm{n}=15$ ). Maximum serum concentrations were attained between Day 6 and 29 and on average on Day 15. These maximum concentrations ranged from $373 \mathrm{pg} / \mathrm{ml}$ to 1837 $\mathrm{pg} / \mathrm{ml}$. As six months, the mean concentrations had declined to on average $387.8 \mathrm{pg} / \mathrm{ml}$ (SD $104.1 \mathrm{pg} / \mathrm{ml}$, $\mathrm{n}=15$ ). From the months 6 assessment onwards, average mean ENG concentrations slowly declined to 316.1 (SD 79.2), 256.7 (SD 47.3), 235.4 (SD 41.9), 222.2 (SD 36.7) and 169.1 (SD 24.8) $\mathrm{pg} / \mathrm{ml}$ at the last assessment periods of year $1(n=15), 2 \quad(n=15), 3$ $(n=15), 4(n=10), 5(n=7)$, respectively.

Table 7 provides frequencies of the number of sub- jects with mean ENG concentrations $<90 \mathrm{pg} / \mathrm{ml}$, 90 $<120 \mathrm{pg} / \mathrm{ml}$ and $>120 \mathrm{pg} / \mathrm{ml}$.

Table 7. Frequency table of mean ENG per assessment

\begin{tabular}{|c|c|c|c|c|}
\hline \multirow{2}{*}{ Assessment } & \multirow{2}{*}{$\mathrm{n}$} & \multicolumn{3}{|c|}{ Number of subjects with concentrations } \\
\hline & & $\begin{array}{l}<90 \\
\mathrm{pg} / \mathrm{ml}\end{array}$ & $\begin{array}{c}90-<120 \\
\mathrm{pg} / \mathrm{ml}\end{array}$ & $\begin{array}{l}>120 \\
\mathrm{pg} / \mathrm{ml}\end{array}$ \\
\hline Week 1 - 6 & 15 & & & 15 \\
\hline Week 24 - 29 & 15 & & & 15 \\
\hline Week $48-53$ & 15 & & & 15 \\
\hline Week $72-77$ & 15 & & & 15 \\
\hline Week $98-104$ & 15 & & & 15 \\
\hline Week $124-129$ & 15 & & & 15 \\
\hline Week $150-155$ & 15 & & & 15 \\
\hline Week $167-170$ & 10 & & & 10 \\
\hline Week $180-183$ & 10 & & & 10 \\
\hline Week 193 - 196 & 10 & & & 10 \\
\hline Week $206-209$ & 10 & & & 10 \\
\hline Week $219-222$ & 6 & & & 6 \\
\hline Week $232-235$ & 7 & & 1 & 6 \\
\hline Week $245-248$ & 7 & & 1 & 6 \\
\hline Week $258-261$ & 7 & & & 7 \\
\hline
\end{tabular}

None of the subjects had mean ENG concentrations $<90$ $\mathrm{pg} / \mathrm{ml}$ during the entire treatment period.

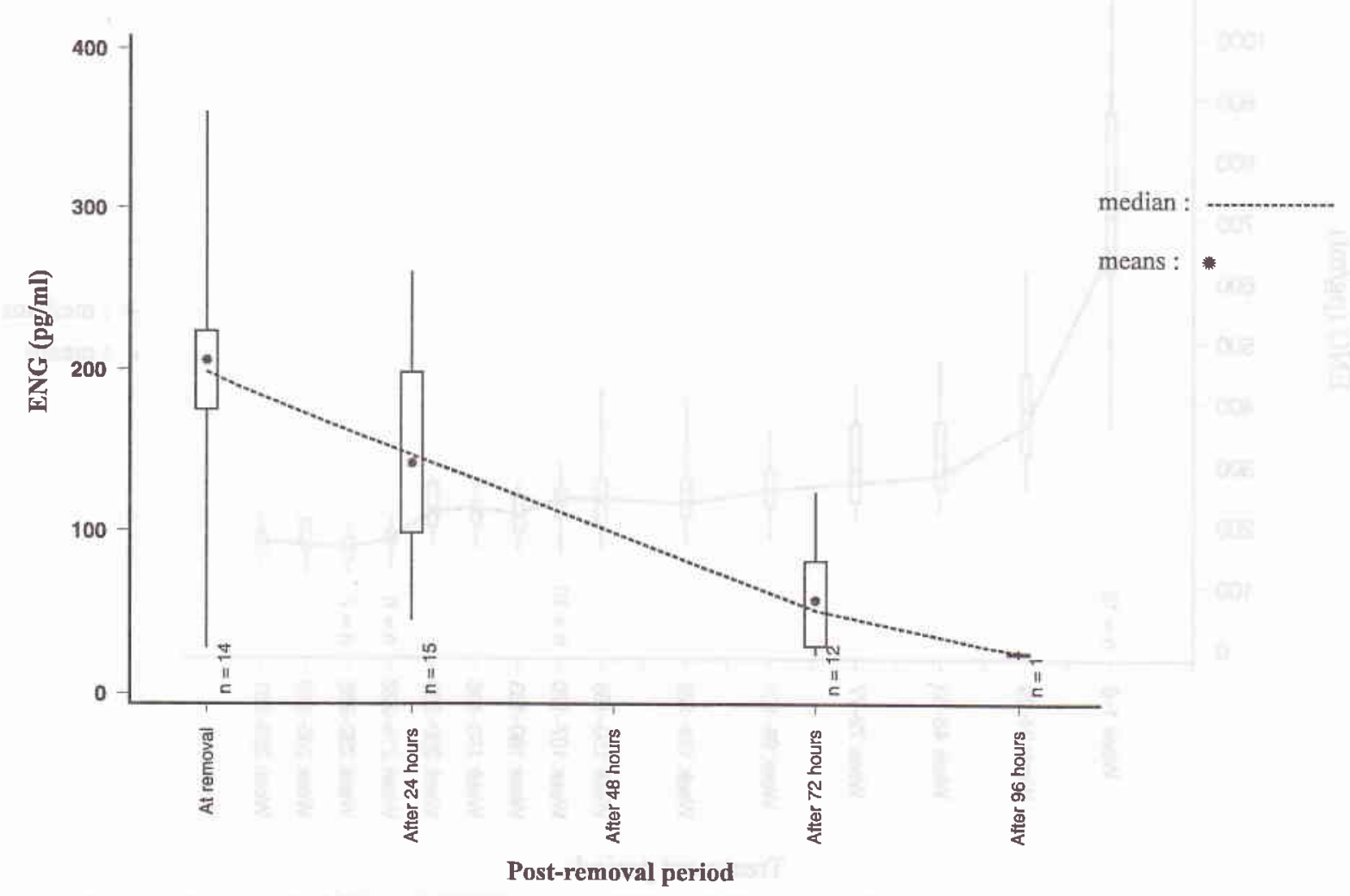

Figure 3. Mean, median, interquartile and P05-95 ranges of mean ENG concentration measured during post-removal. 
After implant removal ENG concentrations rapidly decreased as can be observed from Figure 3, displaying box-plots of ENG concentration assessed either just prior to or just after removal and after 24,72 and/or 96 hours.

\section{Vaginal bleeding patterns}

Figure 4 illustrated the vaginal bleeding patterns according to $\mathrm{WHO}^{15}$.

The mean numbers of bleeding/spotting days were ranged between 17.5 days in reference period XI and 31.7 days in reference period XIX.

The mean numbers of bleeding/spotting episodes were ranged between 1.9 in reference period XI to 3.7 in reference period XIX.

Some amenorrhoea were found in reference period 2 through to reference period 13 .

\section{Contraceptive-efficacy}

During treatment no pregnancies occurred. None of the subjects used condoms or other additional contraceptives during the first three treatment years. After three years other additional contraceptives were used by some subjects from month 39 onwards. No information on condom use is available for this period.

\section{Return of fertility}

There were 10 subjects participated in the fourth year of the study and there were only 7 of them finished the fifth year.

After having the implant removed they were evaluated for return of fertility within three-months after implant removal.

The results are as follows:

- 2 subjects were pregnant

- 5 subjects reported their menses having returned to the normal pre-trial patterns

- 3 subjects did not have their menses returned to normal:

- 2 subjects had luteal phase progesteron levels $(\mathrm{P}=44.9 \mathrm{nmol} / \mathrm{l}$ and $48.2 \mathrm{nmol} / \mathrm{l}$

- 1 subject with $\mathrm{P}=1.2 \mathrm{nmol} / \mathrm{l}$

\section{CONCLUSIONS}

This study, along with other studies, $, 7,8$ demonstrates that ENG contraceptions in Implanon ${ }^{\circledR}$ were sufficient to inhibit ovulation and normal luteal function. Signs of luteinization were rarely observed. E2 levels showed large intra subject and inter subject variation, which indicates that ovarian function was not fully suppressed. There was no pregnancy occured during

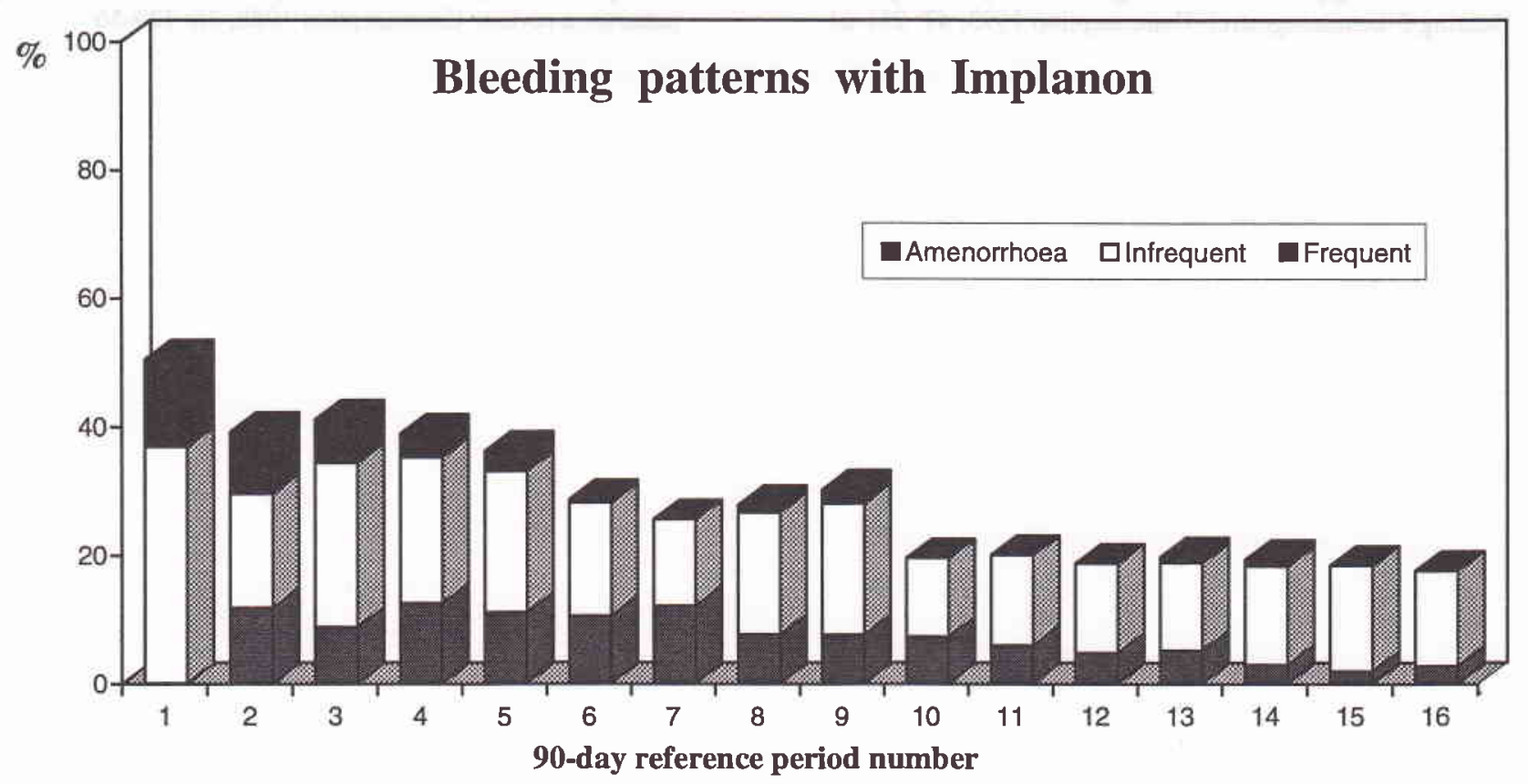

Figure 4. Vaginal bleeding patterns. 
the implant use. As with other progestin only contraceptives, the bleeding patterns were signified by disruption with amenorrhoea, bleeding and spotting.

\section{Acknowledgements}

The study was conducted as part of Implanon ${ }^{\circledR} \mathrm{Re}-$ search and Development Program, sponsored and coordinated by NV Organon, Oss, the Netherlands. Thanks are due to Dr. Stevenson from N.V. Organon Holland for Good Clinical Practice Monitoring, to Drs. Wardoyo Gadroen, Bandar Manik and Susilo from Organon Indonesia for study monitoring, to Dra. Rosminah from Klinik Raden Saleh for patients coordination, to Drs. AGM Theeuwes and RMV Stoleman from SOG NV Organon, Drs. Joedo Prihartono and Sujadi for statistical analysis and to Sofia Yoebhaar for typing the manuscript.

\section{REFERENCES}

1. Affandi B. Clinical, pharmacological and epidemiological studies on a levonorgestrel implant contraception. PhD thesis, University of Indonesia, Jakarta, 1987

2. Coutinho E: Clinical experience with implant contraception. Contraception 1978, 18: 411-27

3. Affandi B, Santoso SSI, Djajadilaga et al. Five year experience with Norplant ${ }^{\circledR}$. Contraception 1987, 36: 417-28

4. Ladipo O, Counthinho M. Contraceptive implants. Current opinion in Obstetrics and Gynecology 1994, 6: 564-9

5. Davies GC, Feng LX, Newton JR, Beek AV, Coelingh-Bennink HJT. Release characteristics, ovarian activity and menstrual bleeding pattern with a single contraceptive implant releasing 3-ketodesogestrel. Contraception 1993, 47: 251-61
6. Geelene JAA, van der Wardt JCT, Voortman G, Moosen GCT, Eenink MJD. Release kinetics of 3-ketodesogestrel from contraceptive implants (Implanon ${ }^{\circledR}$ ) in dogs in comparison with in vitro data. Contraception 1993, 47: 215-26

7. Diaz S, Pavez M, Moo-Young AJ, Bardin CW, Croxatto HB. Clinical trial with 3-ketodesogestrel subdermal implants. Contraception 1991, 44: 393-408

8. Olsson SE, Odlind V, Johansson E. Clinical results with subcutaneous implants containing 3-ketodesogestrel. Contraception 1990, 42: 1-11

9. Edqvist LE, Johansson EDB: Radioimmunoassay of oestrone and oestradiol in human and bovine peripheral plasma. Acta Endocrin (Copenh) 1972, 71: 716-30

10. Thorneycroft IH, Stone SC: Radioimmunoassay of serum progesterone in women receiving oral contraceptive steroids. Contraception 1972, 5: 129-46

11. Bergink EW, Hamburger AD, de Jager E, van der Vies J.: Binding of a contraceptive progestogen Org 2969 and its metabolites to receptor proteins and human sex hormone binding globulin. J Steroid Biochem 1981, 14: 175-83

12. Victor A, Weiner E, Johansson EDB: Sex hormone binding globulin: The carrier protein for d-norgestrel. J Clin Endocrin Metab 1976, 43: 244-7

13. Cullberg G, Lindstedt G, Lundberg PA, Steffensen K : Central and peripheral effects of desogestrel $15-60 \mu \mathrm{g}$ daily for 21 days in healthy female volunteers. Acta Obstet Gynecol Scand Suppl 1982, 111: 21-8

14. Landgren B-M, Unden A-L, Diczfalusy E. Hormonal profile of the cycle in 68 normally menstruating women. Acta Endomecrinal $1980,94: 89-98$

15. Balsey FM, Farley TMM. The analysis of menstrual bleeding patterns: a review. Contraception 1988, 38: 129-56 